\title{
MINING WASTE IN CIRCULAR ECONOMY - LEGISLATIVE ASPECT
}

\author{
Senko Pličanič ${ }^{1}$, Ana Mladenović ${ }^{2}$, Alenka Mauko Pranjić², Petra Vrhovnik² \\ ${ }^{1}$ Faculty of Law, University of Ljubljana, Poljanski nasip 2, 1000 Ljubljana, Slovenia, \\ ${ }^{2}$ Slovenian National Building and Civil Engineering Institute, Dimičeva ulica 12, 1000 Ljubljana, Slovenia \\ senko.plicanic@pf.uni-lj.s
}

\begin{abstract}
A b s t r a c t: One of the common European commitments is a transition towards a green circular economy in which waste is not discarded and considered to be just an environmental problem, but should be recognized as an important potential source of raw materials for industry. In a priority order in waste management activities, introduced by the Waste Directive in 2012, recycling is set just behind the waste prevention and reuse. Many types of waste can be recycled, the most perspective being construction, industrial and mining wastes. The latter are produced and disposed of at mine sites during the excavation and processing of ore and are extremely perspective due to large quantities and remaining of different metals, however still underutilized, with low recycling rate. Many mining wastes are inert and do not releases contaminants into environment, however, some of them are problematic and even require monitoring. Reprocessing of these wastes, which include beneficiation and sequential extraction of valuable metals in the first phase and recycling of residues in both structural and civil engineering in the second phase establishes a zero waste model with several benefits for economy, environment and society. Out of the South-East European countries, North Macedonia has great potential to establish this model. As a consequence of long mining tradition and abundant ore resources, there are many mining and metallurgical tailings, on the other hand vivid economy and numerous sinks for use of recycled materials in construction sector can accommodate these quantities. However, there are open questions in terms of administrative procedures and legislation. What are those obstacles that accompany the smooth establishment of the proposed model from a legislative point of view? This paper deals with the situation in North Macedonia, in terms of opportunities, legislative options and the need to adopt new legislation, taking also into account the current problems in this field in Europe.
\end{abstract}

Key words: circular economy; zero-waste approach; mining waste; construction sector; legislation

\section{INTRODUCTION}

In the circular economy the value of products, materials and resources is maintained for as long as possible, and the generation of waste is minimized. In 2015 the European Commission recognized the importance of establishing transition to the Circular Economy in Europe and its essential contribution to generate new and sustainable competitive advantages for Europe by adopting an ambitious Circular Economy Action Plan (COM, 2015). This action plan identified key five priority areas, Critical raw materials and Construction and demolition among them. In order to further enhance decoupling economic growth from resource use while ensuring longterm competitiveness of the EU, the new Circular Economy Action Plan was established in 2020 with concrete goals for production, consumption, waste management, and market creation for secondary raw materials and targets for priority sectors and value chains including Critical raw materials and Construction and demolition sectors (COM, 2020).
The criticality of raw materials for the EU is determined by their economic importance and geostrategic supply risks. The 2020 EU list of critical raw materials already contains 30 critical raw materials (COM, 2020a) with an addition of four new ones (bauxite, lithium, titanium and strontium), compared to the 2017 list. Critical raw materials are essential for the functioning and integrity of a wide range of industrial ecosystems in Europe and one of the means how to reduce dependency on primary critical raw materials is through circular use of resources, including recycling of waste containing such raw materials.

Mining waste, i.e. waste resulting from the prospecting, extraction, treatment and storage of mineral resources and the working of quarries (EC Directive, 2006), is one of the largest waste streams in Europe. Although several inconsistences exist in reporting of the mining waste quantities (Kulczycka et al., 2020), in 2018 mining and quarrying sector 
produced $26.2 \%$ of total waste in EU-28 or 622 million tonnes, the largest amounts being in Romania (178.6 million tonnes), Bulgaria (106.9 million tonnes) and Sweden (103.6 million tonnes) (Eurostat, 2020). According Lebre et al. (2017) the current systems for managing mining waste are mostly based on linear economy thinking, while development of a circular economy model for the mining industry has several advantages (e.g. Kinnunen et al., 2019) with mining waste being an excellent source of secondary raw materials, including critical raw materials.

Reprocessing of mining waste, which includes beneficiation and sequential extraction of valuable metals and critical raw materials in the first phase and recycling of residues for the construction sector in the second phase, establishes a so called zero waste model with several benefits for economy, environment and society. North Macedonia has one of the greatest potential to establish such model due to its geological, historical and socio-economic characteristics. As a consequence of long mining tradition and abundant ore resources, there are many mining and metallurgical tailings (Serafimovski et al., 2008) and on the other hand vivid economy and numerous sinks for use of recycled materials in construction sector which can accommodate these quantities.

However, there are open questions in terms of administrative procedures and legislation. What are those obstacles that accompany the smooth establishment of the proposed model from a legislative point of view? How to comply with environmental legislation especially in the sense of ending waste status, construction legislations and circular economy policies which encourage use of secondary raw materials?

The present article gives a holistic overview on technological as well as administrative and legislative aspects of recycling secondary raw materials from the tailings and heaps in North Macedonia.

\section{A SECONDARY RAW MATERIALS POTENTIAL FROM MINING WASTE IN NORTH MACEDONIA}

There are seven metallic mineral resources areas in North Macedonia containing iron, manga- nese, nickel, chromium, lead and zinc, copper, wolfram, molybdenum, uranium and gold (Serafimovski et al., 2008) as depicted on Figure 1..

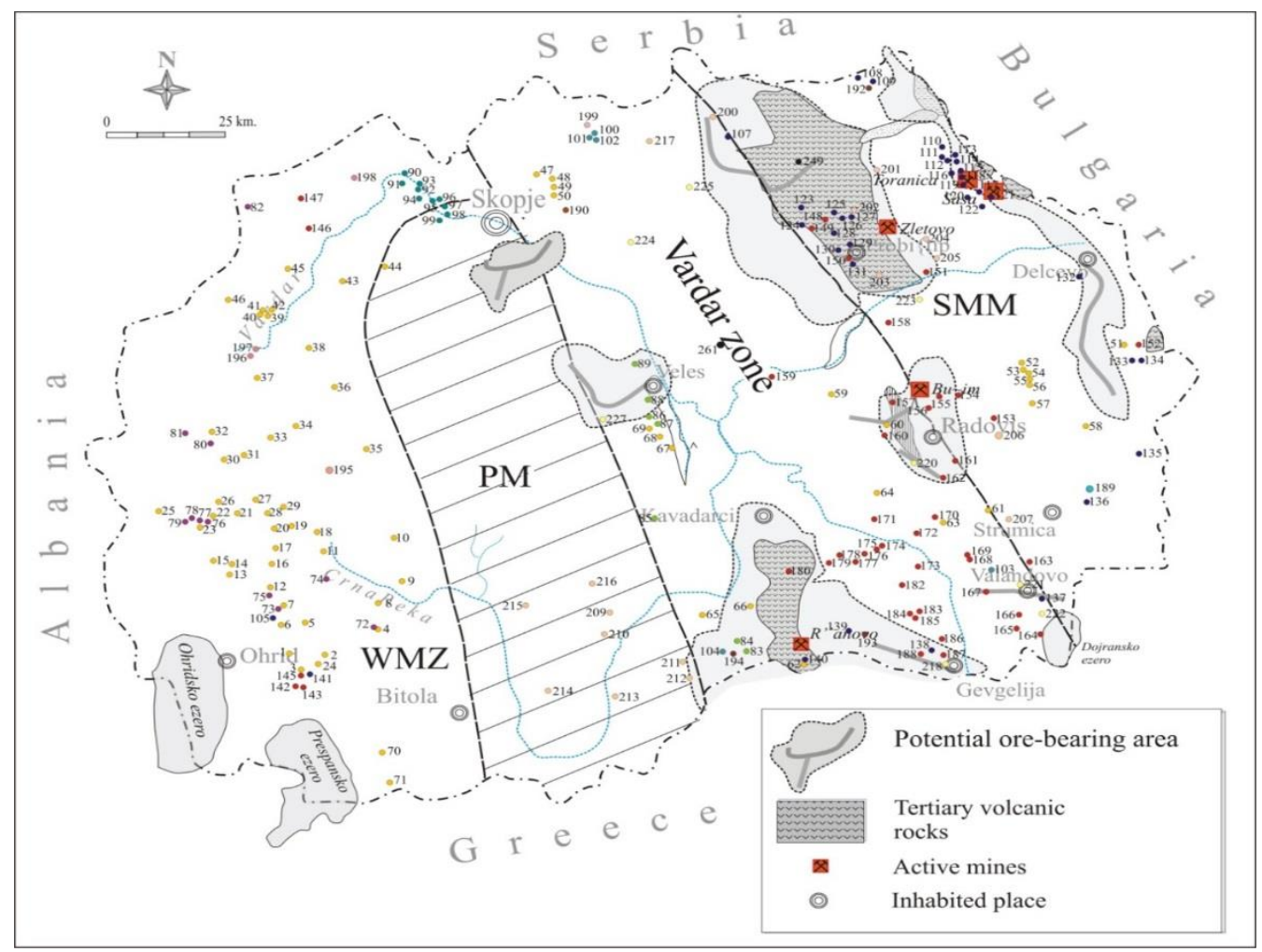

Fig. 1. Metallic mineral resources in North Macedonia are marked with coloured dots (Fe, Mn, Ni, Cr, Pb-Zn, Cu, W, Sb, Mo, U and Au; Serafimovski et al., 2008). 
In some of these areas active mines are operating (e.g. Sasa, Toranica, Zletovo, Bučim, Ržanovo) with mining waste still produced while in others large quantities of waste material from past activities is landfilled, such as $\mathrm{Pb}-\mathrm{Zn}$ deposit in Veles and $\mathrm{Cr}$ deposit in Jegunovce (Šajn et al., 2018). Below is a short description of the largest tailings and heaps in North Macedonia

\subsection{Chromium containing waste heaps}

The smelting facility "Silmak" is located in Jegunovce (NW from the capital of Skopje), between the Vardar river and the railway SkopjeKičevo. The experimental production began in 1955 and had annual production of around 69,000 tonnes (Europeaid, 2007). The factory was permanently closed in 1993. Around 300,000 tonnes of sludge are deposited about $1.5 \mathrm{~km}$ north from town and cover around 8 ha of surface area (Europeaid, 2007). Waste materials containing chromites of calcium, aluminium and sodium (Europeaid, 2007) were mixed with slags to decrease the chromium solubility. The entire dump contains around 2 million tonnes of waste material with high contents of $\mathrm{Cr}^{6+}$ which is especially hazardous to nearby ecosystems.

\subsection{Lead and zinc containing waste heaps and tailings}

Lead and zinc are some of the most important and valuable metallic resources of North Macedonia. The Sasa-Toranica and Zletovo-Kratovo ore deposits are located in the Osogovo Mountains, which are part of the Serbo-Macedonian massif. All lead and zinc deposits are connected with the same geology catchment represented by three metamorphic complexes cross-cut, i.e. by the Strumnica diorite formation, leucocratic gneisses and Tertiary magmatites (Serafimovski et al., 2005). Lead and zinc deposits are accompanied by variable amounts of copper, gold, silver, molybdenum and antimony. Containing of lead and zinc in tailings is diverse among locations. The average content in Zletovo tailings is $0.37 \%$ of lead and $0.32 \%$ of zinc (Vrhovnik et al., in press). It is estimated that inthe Sasa mine, around $0.20 \%$ of zincand $0.40 \%$ of leadare lost during the extraction process and are deposited into the tailings dam that contains almost 20 million $\mathrm{m}^{3}$ of tailing material (Vrhovnik et al., in press). High content of lead and zinc was also established in Veles slag deposit. Based on average sample taken in the RIS-RECOVER project, around $9 \%$ of zinc and $2.8 \%$ of lead has been identified
(Schatzmann et al., 2019), which is higher than previously reported in literature (Šajn et al., 2018).

\subsection{Cooper and gold containing tailings}

North Macedonia has several copper and gold mines, with the majority of them still in the exploration phase. The only currently operating copper mine is the Bucim mine which is operated by the Solway Investment Group Limited of Cypres. The company is currently exploring the Kadica mine as well. There are also several gold projects in the country including the Ilovica gold-copper project. Other gold and copper mining projects under exploration include two exploration concessions being held by reservoir minerals. The Bučim mine waste dump contains around 125 million tonnes of waste materials, containing approximately $0.12 \%$ of $\mathrm{Cu}$ and around 131 million tonnes of tailing material, containing around $0.10-0.15 \mathrm{~g} / \mathrm{t}$ of $\mathrm{Au}$ and around $0.02-0.05 \%$ of $\mathrm{Cu}$ (Serafimovski, 2010; Volkov et al., 2010).

\subsection{Iron and nickel containing tailings}

The Ržanovo deposit, in operation from1956 to 1972 , is located near Kavadarci and consists of peridotites, gabrodolorites and serpentinites (Serafimovski et al., 2013). The iron and nickel orebody is captured between Jurrasic serpentinite and schist in the footwall and Cretaceous limestone in the hanging wall (Serafimovski et al., 2013). The Feni Industry, a metallurgical company which was built before 1980, is processing ore with average grade of nickel $0.92-0.94 \%$. Besides the local source of ores company, Feni processes also imported iron and nickel ores from Albania, Indonesia and Guatemala. The waste slags from pyro-metallurgical processing, furnace and converter contains between 0.08 and $0.13 \%$ of nickel (Boev \&Bermanec; 2005).

\subsection{Antimony and arsenic containing tailings}

The Lojane epithermal arsenic and antimony deposit is located in the north of North Macedonia, close to the border with Kosovo. Exploitation of antimony and arsenic was active between 1923 and 1979 , with annual production capacity from 25,000 to 30,000 tonnes with an average content of $4 \%$ antimony and 5\% arsenic. During active period approximately 90,000 tonnes of waste rock material and around 450,000 tonnes of tailings material were generated. 
Apart from the above listed mineral resources, North Macedonia also has abundant metal resources such as iron, nickel, arsenic, chromium and others. These resources are located in different parts of the country, and contribute significantly to the country's mining sector. However, a lot of minerals occur in small quantities and are currently under exploration.

\section{A ZERO WASTE APPROACH TO RECYCLING MINING WASTE}

\subsection{Extraction of metals and other valuable compounds from mining waste}

Mining waste is excellent resource of metals, especially critical raw materials. On the other hand, once these valuable compounds are extracted, the recycled residues after extraction can be used as secondary raw materials in construction sector, mostly in earthworks such as geotechnical fills and embankments where large quantities of materials can be used. Such approach is called sequential recycling and enables an efficient zero waste approach to mining waste treatment, with no leftovers material. For extraction, different extraction methods can be used, such as pyrometallurgy (i.e. extraction and purification of metals by thermal processes), hydrometallurgy (i.e. a technique that uses chemicals for the recovery of metals from mining waste) or bioleaching (i.e. using autotrophic or heterotrophic bacteria for extraction of metals) (Zhao \& Wang, 2019). Both hydrometallurgy and pyrometallurgy are conducive to the rapid and efficient attainment of metal mixtures, resulting from high temperatures and highly acidic or alkaline conditions, respectively (Aarabi-Karasgani et al., 2010). However, these two processes generate environmental pollutants, such as furans, dioxins, and highly acidic waste water (Gu et al., 2016), meanwhile bioleaching using heterotrophic bacteria is an environmentally friendly technology. Before extraction methods are applied, a beneficiation can be achieved with different physical-mechanical treatments such as gravitational or magnetic separation of minerals crushed and milled to particles of different sizes.

\subsection{Use of residues in construction sector}

Once the valuable metals are extracted, the remaining residues can be used in construction sector either (i) directly, if residues are inert; or (ii) through immobilization processes if residues are non-hazardous or hazardous. In the case of latter the residues are mixed with appropriate additive with binding properties (it can also be a waste material, such as paper ash) in order to prevent leaching of pollutants from the composite. The residue materials can be used in cementitious composites, geotechnical composites or as aggregates (if inert) in different uses, e.g. concrete, asphalt, unbound layers and different applications in earthworks.

\section{LEGAL PERSPECTIVE OF ZERO WASTE RECYCLING OF MINING WASTE}

Recycling of mining waste extends across several legislative areas such as mining, environmental, industrial, construction, industrial emissions and pollution prevention. Among these, the following are inspected in detail covering waste-to-product transition:

- EU Mining Waste Directive (EC Directive, 2006), which is base for classification of waste facilities, technical requirements for waste characterization, definition of inert waste and others;

- EU Waste Framework Directive - WFD EU (EC Directive, 2018), which provides a general framework of waste management requirements and sets the basic waste management definitions; and

\section{- Construction Products Regulation - CPR} (Regulation, 2011), which defines provisions for construction products, including basic requirements for construction works such as use of secondary materials under the sustainable use of natural resources.

\subsection{EU Mining Waste Directive}

The EU Mining Waste Directive provides measures, procedures and guidance to prevent or reduce as far as possible any adverse effects on the environment, in particular water, air, soil, fauna and flora and landscape, and any resultant risks to human health, brought about as a result of the management of waste from the extractive industries. The 
EU Mining Waste Directive defines extractive industries as all establishments and undertakings engaged in surface or underground extraction of mineral resources for commercial purposes, including extraction by drilling boreholes, or treatment of the extracted material. The directive foresees that the EU Member States shall take all necessary measures to ensure that extractive waste is managed without endangering human health and without using processes or methods which could harm the environment and to prohibit the abandonment, dumping or uncontrolled depositing of extractive waste. The operator should also takes all measures necessary to prevent or reduce as far as possible any adverse effects on the environment and human health brought about as a result of the management of extractive waste. This includes the management of any waste facility, also after its closure, and the prevention of major accidents involving that facility and the limiting of their consequences for the environment and human health.

The key requirement of the EU Mining Waste Directive is theWaste Management Plan. The plan sets out the type and quantity of the waste produced, how it is produced and whether there is any treatment performed on it. It assesses the risk to the environment and human health from that waste, and the preventative measures operators will have to take to minimize its impact. If the waste is deposited for longer periods, such areas are called mining waste facilities.

The mining waste facilities are defined in the EU Mining Waste Directive as "any area designated for the accumulation or deposit of extractive waste, whether in a solid or liquid state or in solution or suspension", for the following time-periods:

- No time-period for Category A waste facilities $^{*}$ and facilities for waste characterrized as hazardous in the waste management plan;

- A period of more than six months for facilities for hazardous waste generated unexpectedly;

- A period of more than one year for facilities for non-hazardous non-inert waste;

*A waste facility shall be classified under category A if:

- A failure or incorrect operation, e.g. the collapse of a heap or the bursting of a dam, could give rise to a major accident, on the basis of a risk assessment taking into account factors such as the present or future size, the location and the environmental impact of the waste facility; or

- It contains waste classified as hazardous under Directive 91/689/EEC above a certain threshold; or

- It contains substances or preparations classified as dangerous under Directives 67/548/EEC or 1999/45/EC above a certain threshold.)
- A period of more than three years for facilities for unpolluted soil, non-hazardous prospecting waste, waste resulting from the extraction, treatment and storage of peat and inert waste.

Such facilities are deemed to include any dam or other structure serving to contain, retain, confine or otherwise support such a facility, and also to include, but not be limited to, heaps and ponds, but excluding excavation voids into which waste is replaced, after extraction of the mineral, for rehabilitation and construction purposes.

\subsection{EU Waste Framework Directive}

The EU Waste Directive sets the basic concepts and definitions related to waste management, such as definitions of waste, recycling, recovery. It explains when waste ceases to be a waste and becomes a secondary raw material through end-ofwaste (EoW) criteria, and how to distinguish between waste and by-products. This directive lays down some basic waste management principles: it requires that waste to be managed without endangering human health and harming the environment, and in particular without risk to water, air, soil, plants or animals, without causing a nuisance through noise or odours, and without adversely affecting the countryside or places of special interest. It also sets a priority order for the waste management or so called management hierarchy where Member States should above all set their targets on waste prevention and if this cannot be achieved the following should be aimed at: (i) preparing for reuse, (ii) recycling, (iii) recovery, and as last option (iv) disposal (Figure 2)

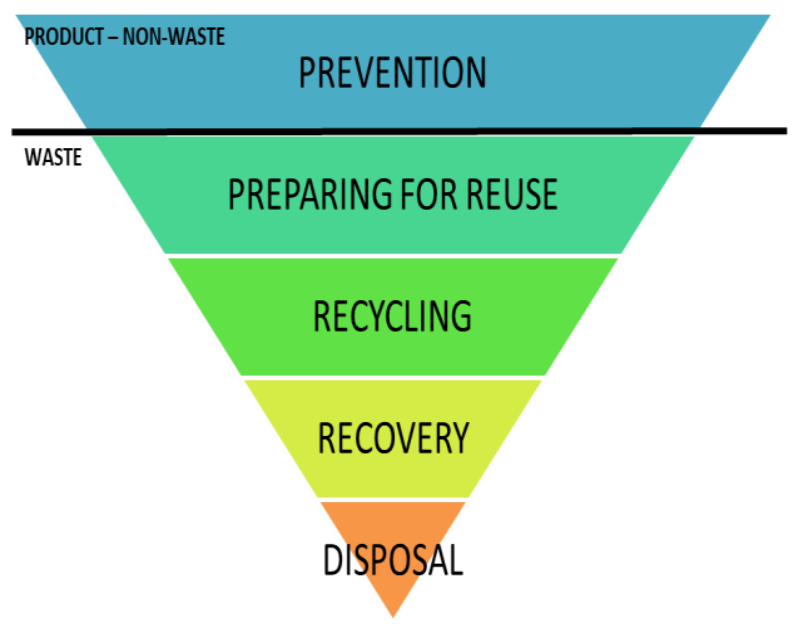

Fig. 2. The waste treatment hierarchy (adopted according to https://ec.europa.eu/environment/waste/framework/) 
Currently there is no common or harmonized EU regulation defining limit values for pollutants in waste intended as secondary raw materials for different construction products. In 2014, the Joint Research Centre (JRC) published a study on methodological aspects for limiting values of pollutants in aggregates (Saveyn et al., 2014). In VLAREMA (2012), the Flemish standard for sustainable management of material and waste cycles, EoW criteria have been established for materials that can be used as building materials (concrete aggregates, crushed masonry, asphalt materials, crushed asphalt sands, etc.). COPRO is a certification body that controls construction product quality for the purpose of these EoW criteria in accordance with the Belgian Decree on general construction conditions. CERTIPRO is another certification body administered by VITO that, among others, handles recycled aggregates. Other national EoW criteria have been adopted by UK (EA, 2013), Austria, France, Basque country, Slovenia and The Netherlands. Furthermore, there is Nordic report available on EoW criteria for CDW (TemaNord, 2016).

\subsection{Construction Product Regulation}

The Construction Products Regulation (Regulation, 2011) lays down harmonized rules for the marketing of construction products in the EU. The regulation sets out methods and criteria for assessing and expressing the performance of construction products, and the conditions for the use of $\mathrm{CE}$ marking. The CE marking indicates that the performance of the product has been assessed and that it remains constant. CE marking enables a construction product to be placed legally on the market in any EU country and then to be traded on the EU's single market.
Based on the potential impact of the construction product on construction work (e.g. building, road, geotechnical work) and their "basic requirements" (i.e. Mechanical resistance and stability, Safety in case of fire, Hygiene, Health \&The Environment, Protection against Noise, Energy Economy \& Heat Retention and Sustainable use of Natural Resources) construction products fall under different control systems, which range from largescale third-party (notified body) involvement to self-declaration and monitoring by the manufacturer.

For products not covered by $\mathrm{hEN}$, a national technical specification (national technical standard or national technical approval) can be issued. The national technical specifications respect the limits imposed by the CPR and comply with other applicable EU legislation, as well as with the provisions governing free movement of goods in non-harmonize sectors.

One of the novelties of the Construction Product Regulation, set in 2011, was adding new basic requirement for construction work, i.e. "Sustainable use of Natural Resources". By this basic requirement the "construction works must be designed, built and demolished in such a way that the use of natural resources is sustainable and in particular ensure: (i) reuse or recyclability of the construction works, their materials and parts after demolition; (ii) durability of the construction works; and (iii) use of environmentally compatible raw and secondary materials in the construction works." By introduction of new basic requirement no practical distinction between primary (natural) raw materials and secondary raw materials is envisioned, what is important are construction product's essential characteristics according to its intended use in the construction work

\section{WASTE LEGISLATION AND POTENTIAL FOR MINING WASTE RECYCLING IN NORTH MACEDONIA}

Currently the laws on waste management and special waste streams according to European legislation have not been adopted yet in the North Macedonia. This also includes lack of systemic approach for remediation of environmental hot spots (SWS, 2020). On the other hand, the existing technical standards for the construction products are very similar to those adopted by the European Committee for Standardization (CEN).

The general waste management is covered by the Law on Waste Management (Official Gazette of the Republic of Macedonia no. 68/2004, 71/2004, 107/07, 102/08, 143/08, 124/10, 09/11; 51/11). The Ministry of Environment and Physical Planning's (MOEPP) tasks and responsibilities in the field of waste management are planning and developing legislation, registration, issuing permits and licensing, organization of an effective solid waste management system for hazardous waste, monitoring, data collection/handling, inspection. The North Macedonia has also adopted several national strategies in the field such as Waste Management 
Strategy (WMS, 2008-2020), The National Waste Management Plan (NWMP, 2009-2015) and draft (NWMP, 2020-2026) and the National Strategy for Sustainable Development (NSSD, 2008).

The Law on Construction (Off. Gaz. 168/18) on the other hand regulates the construction, the basic requirements of the construction works, the necessary project documentation for obtaining a building permit, the rights and the obligations of the participants in the construction, the manner of use and maintenance of construction, as well as other issues of importance for the building. Law on Con- struction Products (Official Gazette of the Republic of Macedonia No. 104/15, 192/15 and 53/16) regulates the conditions for placing the construction product on the market, the system for assessment and confirmation of the consistency of properties, the declaration of properties, the CE marking, the non-harmonized area, the obligations of the economic operators, the harmonized technical specifications, the establishment and the operation of the bodies for technical assessment and the establishment and operation of the appointed bodies, the supervision and control of the product on the market.

\section{CONCLUSIONS}

North Macedonia has a huge potential for reprocessing of mining waste, which has been landfilled at several locations across the country. Extraction of valuable metals and recycling and utilization of residues in building sector are the key steps in this process. In order to attract the investors, the proper environment shall be established, which will enable all the necessary business, legal and procedural activities.

Acknwledgements: This work was supported by the EIT Raw materials project no. KAVA 17128, RIS-RECOVER and H2020 and the H2020 CINDERELA Project 'New Circular Economy Business Model for More Sustainable Urban Construction'. Funding of the latter was provided by the European Union's Horizon 2020 research and innovation programme under grant agreement No. 776751.

\section{REFERENCES}

Arabi-Karasgani, M., Rashchi, F., Mostoufi, N., Vahidi, E. (2010): Leaching of vanadium from LD coverter slag using sulfuric acid. Hydrometallurgy, 102 (1-4), 14-21.

DOI: 10.1016/j.hydromet.2010.01.006

Boev, B. and Bermanec, V. (2005): Phase composition of the slag of the Feni Industry metallurgical plant and its impact on the environment. 3rd International UNESCO-Workshop., pp. 57-66. (http://eprints.ugd.edu.mk/2887/1/intern ational.2005.pdf)

COM (2015): Communication COM (2015) 614 final: Closing the loop - An EU action plan for the Circular Economy. 21 pp, 1 annex European Commission.

COM (2020): Communication COM (2020) 98 final: A new Circular Economy Action Plan for a Cleaner and More Competitive Europe, 19 pp, 1 annex European Commission.

COM (2020a): Communication COM (2020) 474 final: Critical Raw Materials Resilience: Charting a Path towards Greater Security and Sustainability. 23 pp. European Commission.

Regulation (EU) (2011): No 305/2011 of The European Parliament and of The Council of 9 March 2011 laying down harmonized conditions for the marketing of construction products and repealing Council Directive 89/106/EEC. 27 pp, 5 annexes European Commission.

Decree on Waste (Uredba o odpadkih) (Off. Gaz. of RS, no. $37 / 15,69 / 15$ and 129/20).

Directive 2008/98EC. Available on: https://ec.europa.eu/envir onment/waste/framework/

EA (2013): Aggregates from inert waste. Available on: https: //assets.publishing.service.gov.uk/government/uploads/sy stem/uploads/attachment_data/file/296499/LIT_8709_c60 600.pdf.
EC Directive (2006): 2006/21/EC of The European Parliament and of The Council of 15 March 2006 on the management of waste from extractive industries and amending Directive 2004/35/EC.15 pp, 3 annexes European Commission.

Europeaid (2007): Feasibility Study - Volume III: Silmak Chromium Dumpsite - Jegunovce. Available on:

http://www.moepp.gov.mk/wp-content/uploads/2014/11 /Volume\%20III_Silmak_feasibility_final_12_10_07.pdf.

Eurostat (2020): https://ec.europa.eu/eurostat/databrowser/vie w/ten00106/default/table?lang=en.

Gu, Y., Wu, Y., Xu, M., Mu, X., Zuo, T. (2016): Waste electrical and electronic equipment (WEEE) recycling for a sustainable resource supply in the electronics industry in China. J Clean Prod 127, 331-338.

Kinnunen, P. H.-M., Kaksonen, A. H. (2019): Towards Circular Economy in mining: Opportunities and bottlenecks for tailings valorization. Journal of Cleaner Production, 228, 153-160.

Kulczycka, J., Dziobek, E. and Szmiłyk, A. (2020): Challenges in the management of data on extractive waste - the Polish case. Mineral Economics. 33, 341-347. Springer.

Lebre, E., Corder, G., Golev, A. (2017): The role of the mining industry in a Circular Economy. A framework for resource management at the mine site level. J. Ind. Ecol. 0 (0), 1e11.

NWMP (2009-2015): The National Waste Management Plan. Available on: http://www.moepp.gov.mk/?page_id=3194 \&lang=en.

NWMP (2020-2026): Draft of the National Waste Management Plan (in Macedonian). Available on: http://www.moepp.gov.mk/wp-content/uploads/2014/12 /NWMP_202 0_2026_Nacrt.pdf. 
NSSD (2008): National Strategy for Sustainable Development for the Republic of Macedonia (Parts I and II). Available on: http://www.moepp.gov.mk/?page_id=3197\&lang=en

Saveyn, H., Eder, P., Garbarino, E., Muchova, L., Hjelmar, O., Van der Sloot, H., Comans, R., Van Zomeren, A., Hyks, J., Oberender, A. (2014): Study on methodological aspects regarding limit values for pollutants in aggregates in the context of the possible development of end-of-waste criteria under the EU Waste Framework Directive. JRC Directorate.

Schatzmann, W., Antrekowitsch, J., Bergmans, J. (2019): Report on the performed laboratory analysis for the extraction of CRM and metals. EIT RM: RIS-RECOVER.

Serafimovski, T., Tasev, G., Dolenec, T. (2005): Petrological and geochemical features of the Neogene volcanites of the Osgovo mountains, Eastern Macedonia. Materials and Geoenvironment. 52 (3), 523-534.

Serafimovski, T., Čifliganec, V., Tasev, G., (2008): Metallic mineral resources in the Republic of Macedonia. First Geological Congress of Geologists from the Republic of Macedonia, Proceedings, pp. 87-98. [in Macedonian].

Serafimovski, T. (2010): Additional mining project for formation of inner waste dump in the southern part of the Bučim's open pit mine (Book 1: Geological part). Faculty of Natural and Technical Sciences, University "Goce Delčev", Štip, 83 p. [in Macedonian]

Serafimovski, T., Volkov, A., Boev, B., Tasev, G. (2013): Ržanovo metamorphosed lateritic Fe-Ni deposit, Republic of Macedonia. Geology of Ore Deposits. 55. 383-398. 10.1134/S1075701513050073.

SWS (2020): Staff Working Document 351 final. North Macedonia 2020 Report.

Šajn R., Alijagić J., Stafilov T., Boev B., Serafimovski T., Ilijoski Z., Filkoska T., Schatzmann W., Bergmans J. (2018): Deliverable D2.1 Feasibility Report, 30.11.2018

TemaNord (2016): End of waste crietria for construction and demolition waste. Available on: http://www.diva-portal.o rg/smash/get/diva2:1044870/FULLTEXT03

VLAREMA Besluit van de Vlaamse Regering tot vaststelling van het Vlaamsreglementbetreffende het duurzaambeheer van material kring lopen enaf valst offen. 2012. https:// www.ovam.be/vlaamse-wetgeving-0\#materialen (last acc essed: 16/11/2020).

Volkov, A., Serafimovski, T., Stefanova, V. (2010): Formation mechanism of dwarfish $\mathrm{Cu}-\mathrm{Au}$ porphyry deposits of Macedonia. Dokl. Earth Sci. 431, 5, 649-655.

WFD EU: https://eur-lex.europa.eu/legal-content/EN/TXT/PD F/uri=CELEX:32008L0098\&from $=$ EN

WMS (2008-2020): Waste Management Stategy. Available on: http://www.moepp.gov.mk/wp-content/uploads/2014/12 Waste-Management-Strategy-of-the-RM-2008-2020.pdf

Zhao, F., Wang, S. (2019): Chapter 7 - Bioleaching of electronic waste using extreme acidophiles. Eletronic Waste Management and Treatment Technology, 153-174. https://doi.org/10 .1016/B978-0-12-816190-6.00007-8.

Р е 3 и м е

\title{
РУДАРСКИ ОТПАД ВО ЦИРКУЛАРНА ЕКОНОМИЈА - ЗАКОНОДАВЕН АСПЕКТ
}

\author{
Сенко Пличанич ${ }^{1}$, Ана Младеновиќ ${ }^{2}$, Аленка Мауко Прањиќ ${ }^{2}$, Петра Врховник ${ }^{2}$

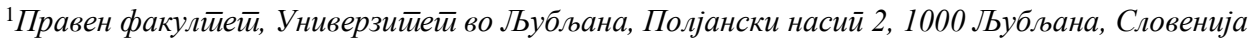

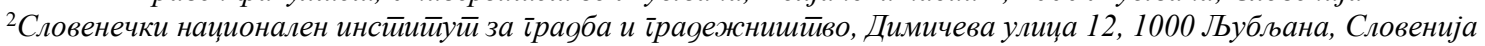 \\ senko.plicanic@pf.uni-lj.si
}

Клучни зборови: циркулирачка економија; пристап нула отпад; отпад од рудници; градежен сектор, законодавство

Една од заедничките европски обврски е транзиција кон зелена циркуларна економија, во која отпадот не се фрла и не се смета само како проблем во животната средина, но треба да се препознае како важен потенцијален извор на суровини за индустријата. По приоритетен редослед во активностите за управување со отпад, воведени со Директивата за отпад во 2012 година, рециклирањето е поставено веднаш зад превенцијата и повторната употреба на отпадот. Многу видови отпад можат да се рециклираат, а најперспективен е градежниот, индустрискиот и рударскиот отпад. Последниот се произведува и се отстранува во рудниците за време на ископувањето и преработката на рудите и е екстремно перспективен поради големото количество и остатоците на различни метали, а сепак недоволно искористен, со мала стапка на рециклирање. Многу отпадоци од рударството се инертни и не ослободуваат загадувачи во околината, но некои од нив сепак се проблематични, па дури бараат и мониторинг. Преработката на овој отпад, кој е збогатен со вредни метали, вклучува и секвенцијална екстракција во првата фаза и рециклирање на остатоците во структурното и градежното инженерство во втората фаза, воспоставува модел на нула отпад со неколку придобивки за економијата, животната средина и општеството. Од земјите на Југоисточна Европа, Северна Македонија има голем потенцијал да го воспостави овој модел. Како последица на долгата рударска традиција и изобилството на рудните ресурси има многу рударски и металуршки јаловишта, но добрата економија и искористувањето на рециклираниот материјал во градежниот сектор можат да придонесат за намалување на количествотоа отпад. Сепак, постојат отворени прашања во однос на административните процедури и законодавството. Кои се тие пречки што го придружуваат непречено воспоставување на предложениот модел од законодавна гледна точка? Овој труд се занимава со ситуацијата во Северна Македонија во однос на можностите, законодавните опции и потребата од усвојување ново законодавство, земајќи ги предвид и тековните проблеми на ова поле во Европа. 